\title{
Monitoring of Soil Water Content in Maize Rotated with Pigeonpea Fallows in South Africa
}

\author{
Misheck Musokwa ${ }^{1,2, *}$, Paramu L. Mafongoya ${ }^{1}$ and Paxie W. Chirwa ${ }^{3}$ (i) \\ 1 School of Agricultural, Earth and Environmental Sciences, University of KwaZulu-Natal, Bag X01, \\ Pietermaritzburg 3209, South Africa; mafongoya@ukzn.ac.za \\ 2 Institute of Natural Resources, P.O. Box 100 396, Pietermaritzburg 3209, South Africa \\ 3 Department of Plant and Soil Sciences, Faculty of Natural and Agricultural Sciences, University of Pretoria, \\ Private Bag X20, Pretoria 0002, South Africa; paxie.chirwa@up.ac.za \\ * Correspondence: mmusokwa@gmail.com
}

Received: 9 June 2020; Accepted: 7 July 2020; Published: 4 October 2020

check for updates

\begin{abstract}
Maize production under smallholder systems in South Africa (RSA) depends on rainfall. Incidences of dry spells throughout the growing season have affected maize yields negatively. The study examined water distribution and water use efficiency (WUE) of maize rotated with two-year pigeonpea fallows as compared to continuous maize without fertilizer. A randomized complete block design, replicated three times, was used with four treatments, which included continuous unfertilized maize, natural fallow-maize, pigeonpea + grass-pigeonpea-maize, and two-year pigeonpea fallow-maize. Soil water mark sensors were installed $0.2 ; 0.5$; and $1.2 \mathrm{~m}$ on each plot to monitor soil water tension $(\mathrm{kPa})$. Soil samples were analyzed using pressure plates to determine water retention curves which were used to convert soil water tension to volumetric water content. Maize rotated with two-year pigeonpea fallows had higher dry matter yield $\left(11,661 \mathrm{~kg} \mathrm{ha}^{-1}\right)$ and WUE $\left(20.78 \mathrm{~kg} \mathrm{~mm}^{-1}\right)$ than continuous maize $\left(5314 \mathrm{~kg} \mathrm{ha}^{-1}\right.$ and $\left.9.48 \mathrm{~kg} \mathrm{~mm}^{-1}\right)$. In this era of water scarcity and drought incidences caused by climate change, maize rotated with pigeonpea fallows is recommended among smallholder farmers in RSA because of its higher WUE, hence food security will be guaranteed.
\end{abstract}

Keywords: agroforestry; drought; maize; pigeonpea; smallholder farmers; watermark sensors; water use efficiency

\section{Introduction}

Agroforestry systems (AFS) are low input systems with a huge potential for sustainable crop production in tropical soils for resource-constrained smallholder farmers. AFS can increase soil infiltration rates through several mechanisms: improved soil structure and porosity, dead tree roots channels [1] and changes in small-scale soil topography. In rain-fed agricultural systems in the semi-arid tropics, water available in the soil profile emanates predominantly from infiltration following rainfall events. AFS with deep roots of trees can bring additional water to the topsoil via hydraulic lift, providing a safety reservoir of water for shallow-rooted crops [2]. In a recent review by Bayala and Prieto [3], it was highlighted that more work was still needed to evaluate the volume of water that is transferred to companion crops by agroforestry tree species through hydraulic lift. Hydraulic lift is thus an ecophysiological process that can guard against droughts, thereby guaranteeing crop productivity in areas experiencing erratic rainfall.

AFS in Africa have been shown to increase water use efficiency (WUE) on long-term field studies conducted in Nigeria and Zambia [4]. WUE is defined as the biomass dry matter or grain yield produced per unit of water utilized [5]. Rain Use Efficiency (RUE) which is similar to WUE was 
measured by Sileshi et al. [4], on two sites (Nigeria and Zambia). In both sites, the RUE in maize grown between leucaena hedgerows was two times higher than in the control of continuous maize grown with no external nutrient inputs [4]. Phiri et al. [6] also recorded similar trends for WUE in sesbania fallows compared to continuous sole maize in eastern Zambia. In another study, in Malawi, Chirwa et al. [7] also obtained higher WUE in maize intercropped with gliricidia than in sole maize and maize intercropped with pigeonpea. However, contrasting results have been reported in semiarid areas where WUE was either higher or lower in sole crops than in intercropped systems. For example, in semi-arid Kenya, higher WUE values were recorded in sorghum when planted in Acacia saligna (Labill.) H.Wendl. alleys than in a sole cropping system for two growing seasons. In the same study, lower WUE values were recorded in cowpea planted in Acacia saligna (Labill.) H.Wendl. alleys than in as sole cropping system [8]. Similarly, in northeast China, a sole cropping system which included sweet potato (Ipomoea batatas (L.) Lam.) and millet (Setaria italica (L.) P. Beauv) recorded higher WUE than when both crops were intercropped with apricot trees [9].

In West Africa, Vitellaria paradoxa, a dominant tree species in agroforestry parklands [10], was found to extract $90 \%$ of its water from the upper soil horizon $(0.10-0.50 \mathrm{~m})$ during the wet season [11]. However, during the dry season when there is limited water supply, the tree utilizes underground water resources by extracting $30 \%$ of its water resources from underground, with $50 \%$ from even deeper soil horizons $(0.3-60 \mathrm{~m})$ [11]. These results provide an indication of how an agroforestry system can overcome limitation of water in dry areas of West Africa. In Ethiopia, an East African country, the quantity of water under Faidherbia albida parklands was found to be two times higher under the tree canopy than outside [12]. Similar trends were reported in Malawi, where the amount of water in 0-0.15 m soil profile was approximately $4-53 \%$ higher under Faidherbia tree canopy than outside [13].

Improved soil structure by AFS can increase soil water-holding capacity, thus enabling the soil to retain moisture for longer after a rainfall event. Regardless of changes in total rainfall, soil water-holding capacity could become very important if rainfall tends to fall in low or larger events. However, other studies have revealed that a remarkable amount of the water received may be lost via soil evaporation or through deep percolation to deep soil profiles beyond crop rooting zone [14-17]. Water use of different crops in the same environment can vary substantially, especially with respect to splitting of evapotranspiration into transpiration, soil evaporation and interception evaporation [18]. Water uptake by roots is controlled by water availability, spatial distribution and biomass of roots, but also by processes in the rhizosphere. When evaluating the water balance of agricultural systems, several components, such as run-off, soil evaporation, and drainage, do not contribute to crop productivity. Although AFS can augment overall yield WUE by minimizing these ineffective constituents [19], there is paucity of information on whether AFS in South Africa (RSA), have higher yield WUE than continuous sole maize cropping without fertilizers [20,21].

Maize (Zea mays L.) is classified as one of the global leading food crops and has become the main raw material source for various industries which include food and feed due to its excellent starch composition [22,23]. In RSA, maize is also grown by smallholder farmers [24]. Maize production on rural households in KwaZulu-Natal province relies heavily on rainfall, and water scarcity has been cited [20], as one of the factors that have affected its productivity. Rotating maize with legume trees, such as pigeonpeas, have been shown to double or triple maize yields [25,26]. Pigeonpea (Cajanus cajan (L.) Millsp.) is one of the most underutilized legume crop in RSA [27]. The crop can be used as human food, livestock feed, firewood and fertilizer [28]. It can also be utilized as a legume base diversification in the country to cater for the increasing need of nutritional foods, as it contains proteins and vitamins, in addition to essential minerals [27]. However, the intercropping of pigeonpeas with maize in agriculture system may confer competition for growth resources, such as soil moisture and sunlight. Presently, quantification of soil moisture and WUE on pigeonpea-maize rotations has received little attention in RSA. As maize production in RSA is heavily reliant on rainfall, occurrence of dry spells during the cropping season can reduce maize yields. In fact, soil water status assumes greater importance in maize cropping systems of smallholder farmers in this era of climate change 
and variability. Notwithstanding, there is a need to investigate WUE in AFS in RSA, since there are encouraging results from various studies elsewhere $[2,4,6,7]$ that showed that AFS may enhance water use under water scarce environments when good management is practiced [29]. In this context, it is important in future for smallholder farmers to receive the correct information on how to utilize scarce rainfall effectively to increase crop productivity, thereby ensuring food security [30]. The present study examined the water distribution of maize rotated with two-year pigeonpea fallows, maize grown after pigeonpea intercropped with grass, maize grown after natural fallow, and continuous maize without fertilizer. The hypothesis was that pigeonpea fallow increases soil water storage for the benefit of subsequent maize and WUE compared with maize in the traditional production system (continuous maize without fertilizer). This research work will provide information on an alternative crop combination in rural farming communities to increase crop productivity and food security in South Africa and elsewhere.

\section{Materials and Methods}

\subsection{Study Site}

The experiment was carried out in the 2015-2016 and 2017-2018 cropping seasons at Fountainhill Estate Farm (latitude $29^{\circ} 27^{\prime} 2^{\prime \prime}$ S; longitude $30^{\circ} 32^{\prime} 42^{\prime \prime} \mathrm{E}$ and altitude $853 \mathrm{~m}$ above sea level) in the uMshwathi Local Municipality, near Wartburg, KwaZulu-Natal, South Africa. The minimum average temperature is $3.3^{\circ} \mathrm{C}$ and the maximum is $37.4^{\circ} \mathrm{C}$. The weather data (rainfall, temperature and vapour pressure deficit) were collected from automatic weather station located within $1 \mathrm{~km}$ from the study site. Composite soil samples made up of 24 subsamples were taken using a $0.02 \mathrm{~m}$ diameter soil auger from $0-0.20 \mathrm{~m}$ soil depth across all the plots before establishing improved pigeonpea fallows in November 2015. The soil samples were analyzed for $\mathrm{pH}, \mathrm{N}, \mathrm{P}, \mathrm{K}$, and organic carbon using procedures described by the International Institute of Tropical Agriculture (IITA) [31]. The soils are classified as ferralsols by the Food and Agriculture Organization of the United Nations (FAO) classification system [32], with sandy loam texture. The results of the soil analysis are shown in Table 1.

Table 1. Soil properties at Fountainhill Estate Farm. Source: Musokwa et al. [28].

\begin{tabular}{cc}
\hline Parameter & Value \\
\hline Nitrogen $(\%)$ & 0.06 \\
Phosphorus $\left(\mathrm{mg} \mathrm{kg}^{-1}\right)$ & 20.4 \\
Potassium $\left(\mathrm{mg} \mathrm{kg}^{-1}\right)$ & 114.2 \\
Calcium $\left(\mathrm{m} \mathrm{kg} \mathrm{k}^{-1}\right)$ & 488 \\
Magnesium $\left(\mathrm{mg} \mathrm{kg}^{-1}\right)$ & 95.6 \\
Copper $\left(\mathrm{mg} \mathrm{kg}^{-1}\right)$ & 2.98 \\
Total cations $\left(\mathrm{cmol} \mathrm{kg}^{-1}\right)$ & 3.594 \\
Organic carbon $(\%)$ & 0.65 \\
pH $(\mathrm{KCl})$ & 4.37 \\
Clay $(\%)$ & 16 \\
\hline
\end{tabular}

\subsection{Experimental Design and Trial Management}

The experiment had four treatments as follows: (1) maize with no fertilizer for 3 continuous seasons (T1); (2) maize sown after a natural fallow which comprised the following grasses: Aragrostis curvula, Bidens pilosa, Cynodon dactylon, and Panicum maximum (T2); (3) maize sown after pigeonpea intercropped with grass in first season and pigeonpea alone on second season (T3); and (4) maize sown after two-year pigeonpea fallows (T4). The optimum fallow period to increase maize production was found to be a cycle of two years of fallow followed by two years of maize cropping [33]. The treatments were laid out in a randomized complete block design and replicated three times. The gross plots were $6 \mathrm{~m} \times 8 \mathrm{~m}$, while the net plots were $7 \mathrm{~m} \times 5 \mathrm{~m}$. The pigeonpea (landrace) was sown on 10 November 2015 as seeds with one seed per planting station at a spacing measuring $1 \mathrm{~m} \times 1 \mathrm{~m}$. The intercrop (maize-pigeonpea) had $1 \mathrm{~m} \times 0.40 \mathrm{~m}$ spacing. Two years after planting (12 November 2017$)$, all the pigeonpea plants were 
removed and the grass from natural fallow was cleared using a hoe. Maize border king variety which matures in approximately 120 days was planted on 22 November 2017, at the spacing of $0.90 \mathrm{~m} \times 0.3 \mathrm{~m}$, and two weeding regimes were undertaken at four and seven weeks after planting using a hand-hoe.

\subsection{Measurement of Soil Water Content and Water Use (WU)}

Measurement procedures have shifted recently from gravimetric soil water techniques based on soil weighing to automated and remotely controlled techniques which use wireless networks [34]. Soil water mark sensors (Campbell Scientific Africa Pvt Ltd., Cape Town, South Africa) are one of the automated and remotely controlled sensors which were installed at $0.20,0.50$, and $1.20 \mathrm{~m}$ depths in each plot and separated by $0.90 \mathrm{~m}$ from each other to monitor soil water tension in situ. These allow continuous monitoring of the soil water status, and there is no soil disturbance once the sensors are installed [34]. The three soil depth used in the study were chosen by taking into account that most agronomic crops, such as maize, have their roots in the soil profile between $0.2-0.5 \mathrm{~m}$ depth, whilst the $1.2 \mathrm{~m}$ depth was selected as it was assumed the pigeonpea tree roots may capture deep soil water $[2,35,36]$. Soil water mark sensor readings were logged automatically, thereby recording every hour soil water tension in kilopascals $(\mathrm{kPa})$ in each treatment. The soil water tension/potential measurements were recorded daily throughout the experiment. The soil moisture retention curves were obtained from uninterrupted soil cores $(0.015 \mathrm{~m}$ height and $0.015 \mathrm{~m}$ diameter) by desorption using standard techniques [37] and analyzed in terms of the empirical retention model of van Genuchten using Retention Curve (RETC) computer program, (United States Environmental Protection Agency, Washington, DC, USA) [38,39]. Moisture retention curves developed on experimental field were used to transform the daily soil water tension in $\mathrm{kPa}$ to volumetric water content $\left(\mathrm{cm}^{3} \mathrm{~cm}^{-3}\right)$.

The quantity of water in the soil profile from the surface to a depth $x$ was calculated by Equation (1).

$$
S(0, x)=\int_{0}^{x} \theta \cdot d x
$$

where $S(0, x)$ is amount of water in the soil ( $\mathrm{mm})$ up to the depth $x, \theta$ is the amount of water content $\left(\mathrm{cm}^{3} \mathrm{~cm}^{-3}\right)$, and $\mathrm{dx}$ is the thickness of soil $(\mathrm{cm})$. Fluctuations in soil water content throughout a given time interval $\left(t=t_{2}-t_{1}\right)$ is given as an integral soil water available in the horizon.

Daily rainfall amounts were used as a direct input into the water balance equation. Runoff and drainage were deemed as insignificant because the study site had a relatively level field with $2 \%$ slope and low rainfall events occurred during the cropping cycle. A change in soil water content within the soil profile was considered as crop water uptake and direct evaporation from the soil. The soil water content for each treatment computed as the entire soil water content within the soil horizon. In this study, water changes were analyzed at the points in time when the water deficit was higher than the rainfall in order to detect effectively any differences due to treatment effects.

$$
\mathrm{ETa}=\mathrm{R}+\Delta \mathrm{W},
$$

where $R$ is the total rainfall $(\mathrm{mm})$ during the maize growing period, and $\Delta \mathrm{W}\left(\mathrm{m}^{-3}\right)$ is the soil water content at sowing subtract soil water content at harvesting for crop rooting zone depth.

\subsection{Sampling of Dry Biomass Matter Yield}

The entire leaves and stalks were collected after every four weeks from planting until harvesting period. These were heated at $105^{\circ} \mathrm{C}$ for $30 \mathrm{~min}$ and then dried at $75^{\circ} \mathrm{C}$ to a constant weight before reweighing. The total above-ground biomass matter yield in each plot was expressed as kg biomass dry-matter ha ${ }^{-1}$. The biomass matter yield was determined based on the average of three plot replicates. All mass values are expressed in relation to the dry weight.

Water use efficiency (WUE) of maize was calculated as the total accumulation of aboveground biomass matter yield $\mathrm{kg} \mathrm{ha}^{-1}$ divided by the total evapotranspiration over the growing period $[5,40]$. 


$$
\mathrm{WUE}=\text { Dry biomass matter yield } \frac{\mathrm{Y}}{\mathrm{ETa}}\left(\mathrm{kg} \mathrm{mm}^{-1}\right),
$$

where $\mathrm{Y}$ is the total accumulation above ground dry biomass matter yield $\left(\mathrm{kg} \mathrm{ha}^{-1}\right)$, and ETa is the total actual evapotranspiration (water used) by maize during the growing season computed using a simplified water balance formula in Equation (2) [5,40].

\subsection{Data Analysis}

Climatic data, such as rainfall, temperature, and vapor pressure deficit, were collected from automatic weather station located around $1 \mathrm{~km}$ radius of the study site. MS Excel 2016 (Microsoft Cooperation, Washington, DC, USA) was used to plot the climatic data, graphs, and trend analysis in analyzing soil water content differences among treatments and soil profiles. Soil water content and total accumulation above ground dry matter yield were recorded for each treatment. The results were subjected to analysis of variance (ANOVA) using GenStat Release 18.2 (VSN International Limited, Hempstead, UK) to establish significant treatment effects. Where significant differences were found on biomass dry matter yield and water use efficiency (WUE), the multiple comparisons using Fisher protected least significant difference (LSD) was used. The actual water use was computed using water balance Equation (2). [40].

\section{Results}

\subsection{Rainfall During Fallow Phase and Post-Fallow Phase}

Figure 1 shows that the total rainfall received from fallow establishment in November 2015 to fallow termination in November 2017 was $1666.4 \mathrm{~mm}$. During the entire pigeonpea fallow phase, the lowest monthly rainfall was received in July 2016, as well as in June and July 2017, which was $4.6 \mathrm{~mm}$, $1.8 \mathrm{~mm}$, and $0.4 \mathrm{~mm}$, respectively, while $156.4 \mathrm{~mm}$ was the highest amount of rainfall received in February 2017. The total rainfall received during post-fallow maize cropping season (November 2017 to April 2018) was $672 \mathrm{~mm}$. The lowest monthly rainfall was received in January 2018, which recorded $47.5 \mathrm{~mm}$, while $145.9 \mathrm{~mm}$ was the highest amount of rainfall received in March 2018 (Figure 2a). The highest-pressure deficit was experienced in September 2017, and it corresponded with the low rainfall in the same month (Figure 1). In the summer of 2017-2018, cropping season, rains were erratic. Heavy rains were experienced in March 2018, while long episodes without rain were predominant in January 2018, which coincided with late vegetative growth of the maize crop.

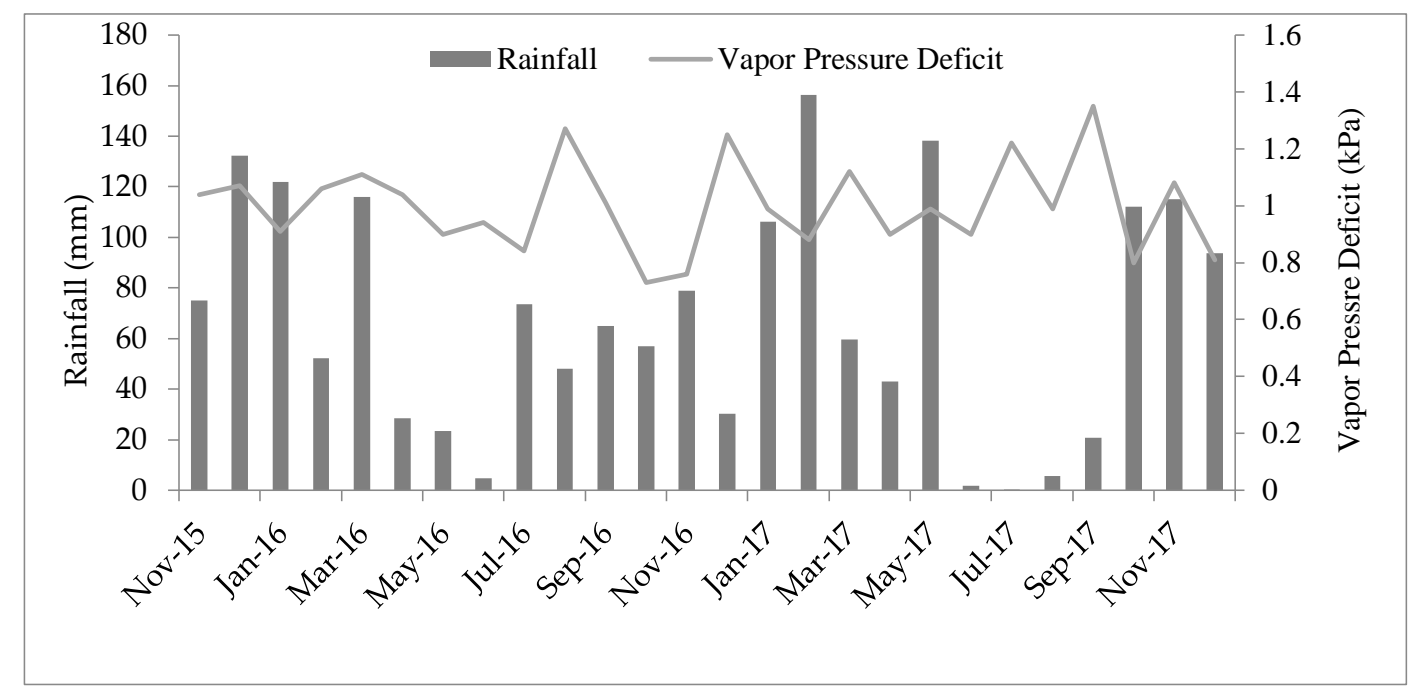

Figure 1. Rainfall and vapor pressure deficit recorded from November 2015 to November 2017 at Fountainhill, Wartburg. 


\subsection{Soil Water Content Within Soil Profiles}

Figure 2 shows the time courses of soil water content changes at the three soil depths during the 2017-2018 summer cropping season. There were no differences among treatments at all soil depths. The soil moisture changes were more apparent in the $0-0.20 \mathrm{~m}$ soil horizon compared to the other soil depths (Figure 2b). Rainfall events were usually associated with increased soil moisture content. For example, in January, after a dry spell, the average soil moisture increased ten times from $0.025 \mathrm{~cm}^{3} \mathrm{~cm}^{-3}$ to $0.25 \mathrm{~cm}^{3} \mathrm{~cm}^{-3}$. The $0.50 \mathrm{~m}$ soil depth only showed a marked soil water content decrease 15 days after rainfall event (Figure 2c). The $1.20 \mathrm{~m}$ soil depth did not show any response to rainfall events (Figure $2 \mathrm{~d}$ ). During initial establishment of the trial at $0.20 \mathrm{~m}$ depth, maize planted on two-year improved fallow had higher soil water content of $0.24 \mathrm{~cm}^{3} \mathrm{~cm}^{-3}$, while continuous maize had $0.21 \mathrm{~cm}^{3} \mathrm{~cm}^{-3}$. Soil water content was generally higher in December 2017 than in January 2018 in all treatments. The average soil water content among all treatments decreased from $0.24 \mathrm{~cm}^{3} \mathrm{~cm}^{-3}$ to $0.026 \mathrm{~cm}^{3} \mathrm{~cm}^{-3}$ on the $0.20 \mathrm{~m}$ profile (Figure $2 \mathrm{~b}$ ), while $0.50 \mathrm{~m}$ profile decreased from $0.49 \mathrm{~cm}^{3} \mathrm{~cm}^{-3}$ to $0.39 \mathrm{~cm}^{3} \mathrm{~cm}^{-3}$ (Figure 2c).

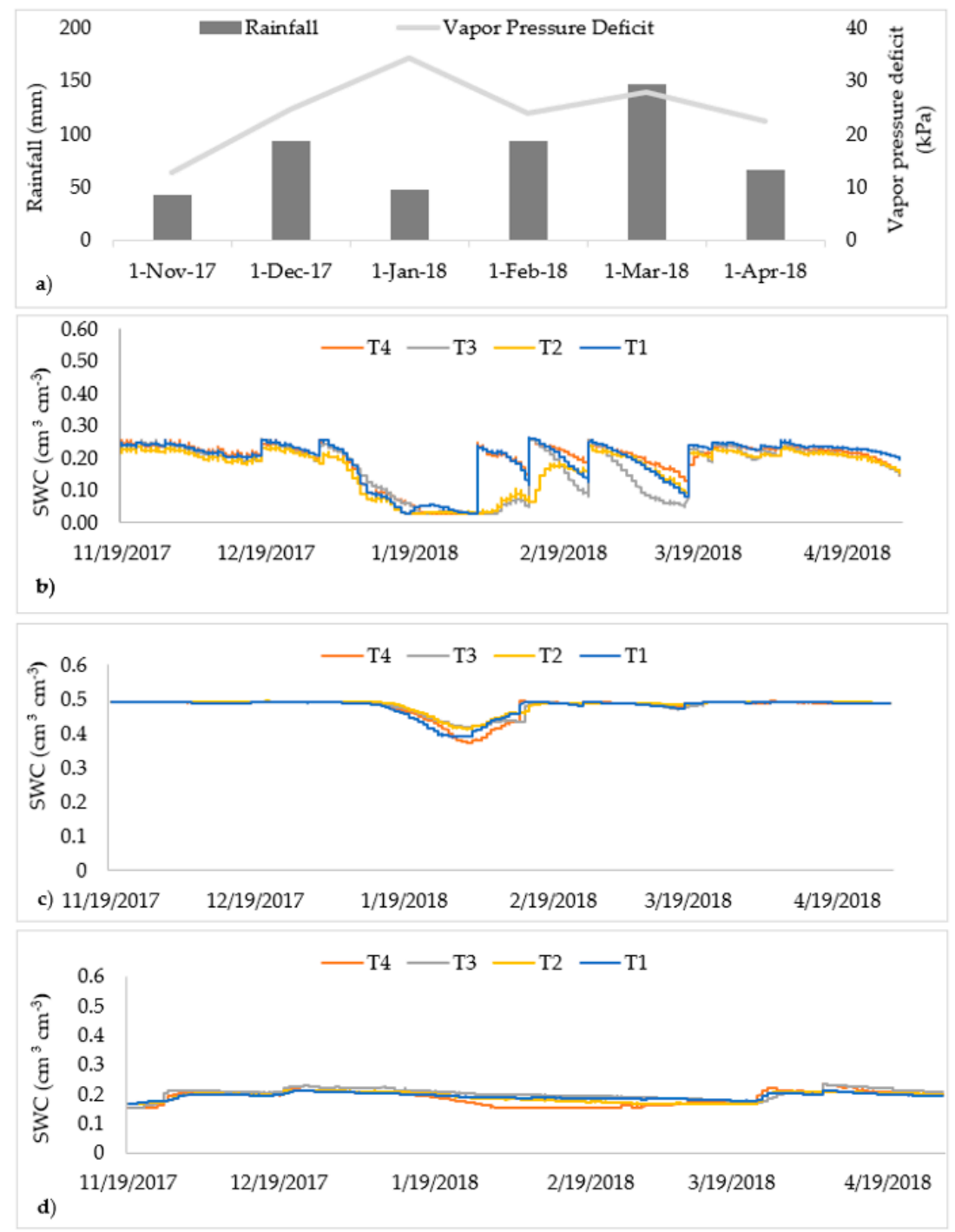

Figure 2. Monthly rainfall and vapor pressure deficit and soil water distribution at each soil depth: $0.20 \mathrm{~m}, 0.50 \mathrm{~m}$, and $1.20 \mathrm{~m}$ on continuous maize without fertilizer (T1); natural fallow, then maize (T2); pigeonpea + grass, then maize (T3); and two-year pigeonpea fallow, then maize (T4). (a) Monthly rainfall and vapor pressure recorded during 2017-2018 cropping season; (b) Soil water content recorded on $0.20 \mathrm{~m}$ soil profile; (c) Soil water content recorded on $0.50 \mathrm{~m}$ soil profile; (d) Soil water content recorderd on $1.2 \mathrm{~m}$ soil profile. 


\subsection{Total Actual Evapotranspiration / Water Use (WU)}

To determine treatment differences in terms of soil moisture content, several dates with low soil water content and associated with higher vapour deficit than rainfall were plotted to observe treatment differences (Figure 3). There were no differences in soil moisture content observed across treatments at all soil depths as shown on (a) 29 November 2017, (b) on 18 January 2018, (c) on 16 March 2018, and (d) on 30 April 2018. However, a significant difference was observed on seasonal water use (WU) which was determined for the period between maize planting in November 2017 and April 2018 where continuous maize without fertilizer $(560.4 \mathrm{~mm})$ had a significantly lower WU than maize grown in a plot after two-year pigeonpea fallow $(561.3 \mathrm{~mm})$. The WU of maize in the four cropping systems (T1, T2, T3, and T4) during the 2017-2018 season was 560.4, 560.4, 561.1, and $561.3 \mathrm{~mm}$, respectively.


Figure 3. Soil water content within 0-1.20 m soil profile: (a) on 29 November 2017, (b) on 18 January 2018, (c) on 16 March 2018, and (d) on 30 April 2018 on continuous maize without fertilizer (T1); natural fallow, then maize (T2); pigeonpea + grass, then maize (T3); and two-year pigeonpea fallow, then maize (T4).

\subsection{Total Cumulative Biomass Matter Yield}

There were highly significant differences $(p \leq 0.001)$ in total dry matter biomass yield between the treatments (Figure 4). The highest total biomass matter yield of $11,661 \mathrm{~kg} \mathrm{ha}^{-1}$ was recorded in maize sown after two-year pigeonpea fallows followed by maize sown after grass + pigeonpea-pigeonpea $\left(8814 \mathrm{~kg} \mathrm{ha}^{-1}\right)$ and the lowest was continuous maize with no fertilizer $\left(5314 \mathrm{~kg} \mathrm{ha}^{-1}\right)$. 


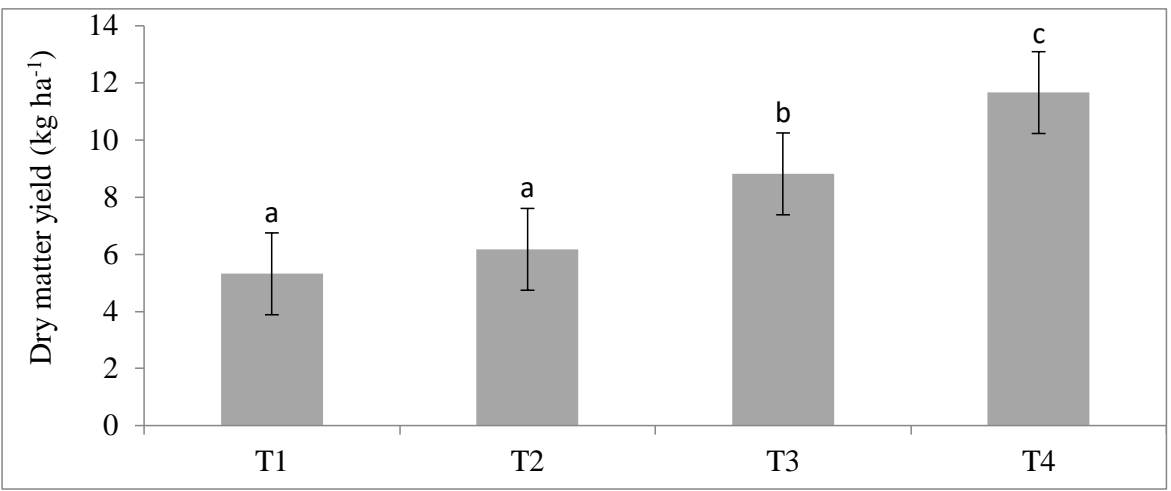

Figure 4. Above ground dry biomass matter yield of maize rotated with pigeonpea fallows. Means in each column with different superscripts are significantly different $(p \leq 0.05)$, according to Fisher's protected LSD.

\subsection{Water Use Efficiency (WUE)}

The effect of improved fallows on WUE is presented in Figure 5. The results indicate significant differences $(p \leq 0.05)$ in terms of WUE. Maize grown after two-year pigeonpea improved fallow-T4 $\left(11.52 \mathrm{~kg} \mathrm{~mm}^{-1}\right)$ outperformed all the treatments, while continuous maize without fertilizer-T1 $\left(5.42 \mathrm{~kg} \mathrm{~mm}^{-1}\right)$ had the lowest WUE.

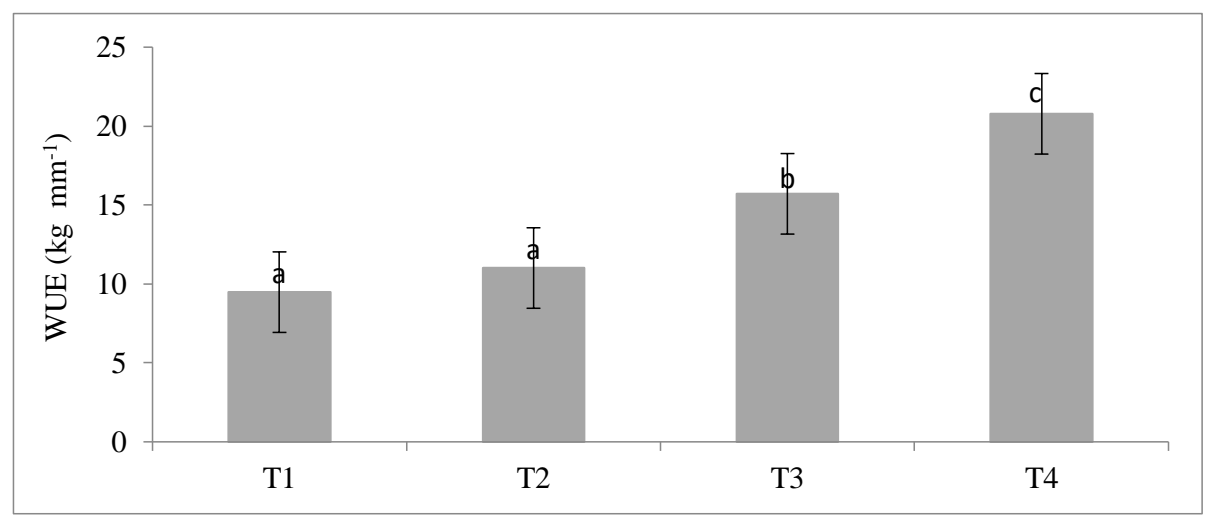

Figure 5. Water use efficiency (WUE) of maize grown after improved fallow systems. Means in each column with different superscripts are significantly different $(p \leq 0.05)$, according to Fisher's protected LSD.

\section{Discussion}

The rainfall for the 2017-2018 summer cropping season was far below the normal season. The rainfall was not evenly distributed, with the least rains received during germination and late vegetative growth with most rains received during grain filling stage. Maize planted after two-year pigeonpea fallows had the greatest total accumulation dry matter as compared to continuous maize without fertilizer. Increase in total above ground biomass yield may be a result of improved physical soil properties. Our results agree with Chirwa et al. [7] and Tian et al. [23], where they found that maize grown after two-year of sesbania and pigeonpea fallows had higher dry matter yield than that continuous maize without fertilizer.

Variations in soil water content were principally affected by the quantity of precipitation received at a certain timeframe. Bullied and Martin [41] noted a similar trend of greater moisture recharge associated with higher precipitation levels. The volume of water stored at the $0.20 \mathrm{~m}$ across all the treatments was lowest in January 2018 which coincided with low rainfall period and the maize crop was at late vegetative growth. Moreover, fluctuations were greater on the upper soil profile, which probably suggest water uptake by maize plants and direct soil evaporation. These results corroborate 
with studies by Asbjornsen et al. [35] and Wang et al. [36], where they found that maize crop uptake water occurs mostly from $0-0.50 \mathrm{~m}$ horizon. This contradicts the findings of this study, where the 0.50 $\mathrm{m}$ soil profile had the highest soil moisture content. It is likely that the water from the $0-0.20 \mathrm{~m}$ soil zone may have drained further down into the $0.20-0.50 \mathrm{~m}$ soil profile. However, this was not the case at $1.20 \mathrm{~m}$. The possible reason for having low soil water content at $1.20 \mathrm{~m}$ could be that water had not reached the deeper soil horizon, likely due to below normal precipitation $(880 \mathrm{~mm})$ for the season, with only $672 \mathrm{~mm}$ received. In addition, the whole root zone may have been using the soil water at $0.20 \mathrm{~m}$ and $0.50 \mathrm{~m}$, thereby possibly restricting water movement to deeper soil horizon.

The lack of noticeable contrasting differences on treatment on soil water throughout the study period possibly implies the utilization of same amount of water. It was assumed that differential soil water content on specific dates recorded during water deficits during the cropping season would provide clear treatment differences.

Pigeonpea fallows had higher WU as compared to continuous maize without fertilizer. The higher WU in two-year improved pigeonpea fallows (T4), might have been due to good crop stand, due to leaf litter fall and high organic matter, which in turn improves soil biological and physical soil properties. Chirwa et al. [7] noted that sole maize without fertilizer had higher water use, and they were not able to separate direct soil evaporation from transpiration, which probably attributed to a lot of direct soil evaporation in unfertilized crops that is contrary with the results. In the future, to determine the actual water used by each treatment or cropping system, there is a need for the use of sap flow gauges [42]. This method quantifies the amount of water exploited throughout the assemblage of dry matter, hence giving reliable figures of WUE for each treatment or cropping system [42].

Maize grown after two-year pigeonpea improved fallows had the highest WUE, which is probably due to higher biomass matter yield. Apart from increasing biomass dry matter yield, enhanced soil fertility promotes whirlwind development of the cover that protects the soil surface, hence minimizing the portion of the entire water that is evaporated [43]. Phiri et al. [6] in Eastern Zambia, recorded 3 times higher WUE on two-year sesbania sesban improved fallows than continuous maize without fertilizer. The results concur with the results by Meena et al. [44], who concluded that plants with higher yield must also have higher WUE. In water scarce environments where there is only rain-fed agriculture, smallholder farmers must conserve soil moisture throughout fallow duration to enhance soil water availability during the subsequent cropping season. More research is required to validate soil water values under the study, particularly in contrasting soil characteristics and different environments. The research work is valuable as it shows the potential of the use of improved pigeonpea fallows to increase water use efficiency in maize based smallholder farmers' fields that are experiencing erratic rainfall due to climate variability.

\section{Conclusions}

The results showed that biomass matter yield and WUE for maize grown after a two-year pigeonpea fallow was two times higher than in continuous maize without fertilizer. We, therefore, conclude that a two-year improved pigeonpea fallow system followed by maize cropping has the potential to improve both yield and water use in rain-fed agriculture systems of Kwazulu-Natal (KZN). Pigeonpea is an important component in Indian dishes in KZN. It is therefore recommended that smallholder famers in drought and water limited environments in South Africa should adopt a two-year pigeonpea fallow-maize cropping system to increase food security.

Author Contributions: Conceptualization and editing by P.L.M.; investigation, draft preparation, and review by M.M.; formal analysis and editing by P.W.C. All authors read and agreed to the published the draft manuscript.

Funding: Water Research Commission of South Africa (WRC) provided funding for this work under project number K5/2492//4. Titled Water use of agroforestry systems for food, forage, and/or biofuel production.

Acknowledgments: We are indebted to Fountainhill Estate Farm for the provision of the study site.

Conflicts of Interest: The authors declare no conflict of interest. 


\section{References}

1. Chirwa, T.; Mafongoya, P.; Chintu, R. Mixed planted-fallows using coppicing and non-coppicing tree species for degraded Acrisols in eastern Zambia. Agrofor. Syst. 2003, 59, 243-251. [CrossRef]

2. Caldwell, M.M.; Richards, J.H. Hydraulic lift: Water efflux from upper roots improves effectiveness of water uptake by deep roots. Oecologia 1989, 79, 1-5. [CrossRef] [PubMed]

3. Bayala, J.; Prieto, I. Water acquisition, sharing and redistribution by roots: applications to agroforestry systems. Plant Soil 2019. [CrossRef]

4. Sileshi, G.W.; Akinnifesi, F.K.; Ajayi, O.C.; Muys, B. Integration of legume trees in maize-based cropping systems improves rain use efficiency and yield stability under rain-fed agriculture. Agric. Water Manag. 2011, 98, 1364-1372. [CrossRef]

5. Hatfield, J.L.; Sauer, T.J.; Prueger, J.H. Managing soils to achieve greater water use efficiency. J. Agron. 2001, 93, 271-280. [CrossRef]

6. Phiri, E.; Verplancke, H.; Kwesiga, F.; Mafongoya, P. Water balance and maize yield following improved sesbania fallow in eastern Zambia. Agrofor. Syst. 2003, 59, 197-205. [CrossRef]

7. Chirwa, P.W.; Ong, C.K.; Maghembe, J.; Black, C.R. Soil water dynamics in intercropping systems containing Gliricidia sepium, pigeonpea and maize in southern Malawi. Agrofor. Syst. 2007, 69, 29-43. [CrossRef]

8. Droppelmann, K.J.; Lehmann, J.; Ephrath, J.E.; Berliner, P.R. Water use efficiency and uptake patterns in a runoff agroforestry system in an arid environment. Agroforest. Syst. 2000, 49, 223-243. [CrossRef]

9. Bai, W.; Sun, Z.; Zheng, J.; Du, G.; Feng, L.; Cai, Q.; Yang, N.; Feng, C.; Zhang, Z.; Evers, J.B.; et al. Mixing trees and crops increases land and water use efficiencies in a semi-arid area. Agric. Water Manag. 2016, 178, 281-290. [CrossRef]

10. Bayala, J.; Wallace, J.W. The water balance of mixed tree-crop systems. In Tree-Crop Interaction: Agroforestry in a Changing Climate; Black, C., Wilson, J., Ong, C.K., Eds.; CABI: London, UK, 2015.

11. Bargués-Tobella, A.; Hasselquist, N.; Bazié, H.; Nyberg, G.; Laudon, H.; Bayala, J.; Ilstedt, U. Strategies trees use to overcome seasonal water limitation in an agroforestry system in semiarid West Africa. Ecohydrology 2017, 10, e1808. [CrossRef]

12. Kamara, C.S.; Haque, I. Faidherbia albida and its effects on Ethiopian highland Vertisols. Agrofor. Syst. 1992, 18, 17-29. [CrossRef]

13. Rhoades, C. Seasonal pattern of nitrogen mineralization and soil moisture beneath Faidherbia albida (synAcacia albida) in central malawi. Agrofor. Syst. 1995, 29, 133-145. [CrossRef]

14. Wallace, J.S. The water balance of mixed tree-crop systems. In Tree-Crop Interactions in Agroforestry Systems: A Physiological Approach; Ong, C.K., Huxley, P.A., Eds.; CAB International: Wallingford, UK, 1996; pp. 189-233.

15. Lin, B. The role of agroforestry in reducing water loss through soil evaporation and crop transpiration in coffee agroecosystems. Agric. For. Meteorol. 2010, 150, 510-518. [CrossRef]

16. Ong, C.K.; Black, C.R.; Marshall, F.M.; Corlett, J.E. Principles of resource capture and utilization of light and water. In Tree-Crop Interactions in Agroforestry Systems: A Physiological Approach; Ong, C.K., Huxley, P.A., Eds.; CAB International: Wallingford, UK, 1996; pp. 73-158.

17. Ong, C.K.; Black, C.R.; Muthuri, C.W. Modifying forests and agroforestry for improved water productivity in the semiarid tropics. CAB Rev. Perspect. Agric. Vet. Sci. Nutr. Nat. Resour. 2006, 65, 1-19.

18. Hörmann, G.; Herbst, M.; Eschenbach, C. Water relations at different scales. In Ecosystem Organization of a Complex Landscape; Fränzle, O., Kappen, L., Blume, H.-P., Dierssen, K., Eds.; Springer: Berlin/Heidelberg, Germany, 2008; pp. 101-117.

19. Ong, C.K.; Wilson, J.; Deans, D.; Mulayta, J.; Raussen, T.; Wajja-Musukwe, N. Tree-crop interactions: Manipulation of water use and root function. Agric. Water Manag. 2020, 53, 171-186. [CrossRef]

20. Everson, C.; Ghehezi, S.; Everson, T.M.; Annandale, J. Agroforestry systems for improved food production through the efficient use of water-Final report for WRC Project No. K5/1480. Presented at WRC Reference Group Meeting, Pretoria, South Africa, 16 November 2011.

21. Everson, C.; Dye, P.; Gush, M.; Everson, T. Water use of grasslands, agroforestry systems and indigenous forests. Water Sa 2011, 37, 781-788. [CrossRef]

22. Kang, Y.; Chen, M.; Wan, S. Effects of drip irrigation with saline water on waxy maize (Zea mays L. var. ceratina Kulesh) in North China Plain. Agric. Water Manag. 2010, 97, 1303-1309. [CrossRef] 
23. Tian, M.; Tan, G.; Liu, Y.; Rong, T.; Huang, Y. Origin and evolution of Chinese waxy maize: Evidence from the Globulin-1 gene. Genet. Resour. Crop. Evol. 2008, 56, 247-255. [CrossRef]

24. Mashingaidze, K. Farmer-participatory maize (Zea mays L.) cultivar evaluation and selection in Eastern Cape Province of South Africa. In Proceedings of the 2006 International Plant Breeding Symposium, Mexico City, Mexico, 20-25 August 2006.

25. Abunyewa, A.A.; Karbo, K.N. Improved fallow with pigeonpea for soil fertility improvement and to increase maize production in smallholder crop-livestock farming system in the sub humid zone of Ghana. Land Degrad. Dev. 2005, 16, 447-454. [CrossRef]

26. Akinnifesi, F.K.; Chirwa, P.W.; Ajayi, O.C.; Sileshi, G.; Matakala, P.; Kwesiga, F.R.; Harawa, H.; Makumba, W. Contributions of agroforestry research to livelihood of smallholder farmers in Southern Africa: 1. Taking stock of the adaptation, adoption and impact of fertilizer tree options. Agriculture 2008, 3, 58-75.

27. Hluyako, L.L.; Odindo, A.O.; Mafongoya, P.; Sithole, N.J.; Magwaza, L.S. Characterisation of pigeon pea (Cajanus cajan) landraces grown in two climatic zones in KwaZulu-Natal province, South Africa. S. Afr. J. Plant Soil 2017, 34, 191-199. [CrossRef]

28. Musokwa, M.; Mafongoya, P.; Lorentz, S. Evaluation of agroforestry systems for maize (Zea mays) productivity in South Africa. S. Afr. J. Plant Soil 2018, 36, 65-67. [CrossRef]

29. Hatfield, J.L.; Dold, C. Water-use efficiency: advances and challenges in a changing climate. Front. Plant Sci. 2019, 10, 103. [CrossRef]

30. Chami, D.E.; Moujabber, M.E. Drought, climate change and sustainability of water in agriculture: A roadmap towards the NWRS2. S. Afr. J. Sci. 2016, 112, 9-10. [CrossRef]

31. International Institute of Tropical Agriculture (IITA). Selected Methods for Soil and Plant Analysis; (Manual Series); IITA: Ibadan, Nigeria, 1979; pp. 3, 6, 7, 10-12, 14-15.

32. Faye, M. Soils of South Africa; Cambridge University Press: Cape Town, South Africa, 2010; p. 287.

33. Mafongoya, P.L.; Dzowela, B.H. Biomass production of tree fallows and their residual effect on maize in Zimbabwe. Agrofor. Syst. 1999, 47, 139-151. [CrossRef]

34. Bogena, H.R.; Huisman, J.A.; Oberdörster, C.; Vereecken, H. Evaluation of a low-cost soil water content sensor for wireless network applications. J. Hydrol. 2007, 344, 32-42. [CrossRef]

35. Asbjornsen, H.; Mora, G.; Helmers, M.J. Variation in water uptake dynamics among contrasting agricultural and native plant communities in the Midwestern U.S. Agric. Ecosyst. Environ. 2007, 121, 343-356. [CrossRef]

36. Wang, P.; Song, X.; Han, D.; Zhang, Y.; Liu, X. A study of root water uptake of crops indicated by hydrogen and oxygen stable isotopes: A case in Shanxi Province, China. Agric. Water Manag. 2010, 97, 475-482. [CrossRef]

37. Klute, A. Water retention: Laboratory methods. In Methods of Soil Analysis: Physical and Mineralogical Methods, Part 1, 2nd ed.; Klute, A., Ed.; Agronomy Monographs 9; American Society of Agronomy: Madison, WI, USA, 1986; pp. 635-662.

38. van Genuchten, M.T. A closed-form equation for predicting the hydraulic conductivity of unsaturated soils. Soil Sci. Soc. Am. J. 1980, 44, 892-898. [CrossRef]

39. van Genuchten, M.V.; Leij, F.J.; Yates, S.R. The RETC Code for Quantifying the Hydraulic Functions of Unsaturated Soils; U.S. Government Printing Office: Washington, DC, USA, 1991; p. 85.

40. Cucci, G.; LaColla, G.; Boari, F.; Mastro, M.A.; Cantore, V. Effect of water salinity and irrigation regime on maize (Zea mays L.) cultivated on clay loam soil and irrigated by furrow in Southern Italy. Agric. Water Manag. 2019, 222, 118-124. [CrossRef]

41. Bullied, W.J.; Entz, M.H. Soil water dynamics after alfalfa as influenced by crop termination technique. Agron. J. 1907, 91, 294-305. [CrossRef]

42. Lott, J.E.; Khan, A.A.H.; Black, C.R.; Ong, C.K. Water use by trees and crops in a Grevillea robusta-based overstorey agroforestry system in semi-arid Kenya. For. Ecol. Manag. 2003, 180, 45-59. [CrossRef]

43. Cooper, P.J.M.; Gregory, P.J.; Keatinge, J.D.H.; Brown, S.C. Effect of fertilizer variety and location on barley production under rainfed conditions in northern Syria. Field Crops Res. 1987, 16, 67-84. [CrossRef]

44. Meena, B.L.; Singh, A.K.; Phogat, B.S.; Sharma, H.B. Effects of nutrient management and planting systems on root phenology and grain yield of wheat. Indian J. Agric. Sci. 2013, 83, 627-632.

(C) 2020 by the authors. Licensee MDPI, Basel, Switzerland. This article is an open access article distributed under the terms and conditions of the Creative Commons Attribution (CC BY) license (http://creativecommons.org/licenses/by/4.0/). 